\title{
The impact of Raccoons Procyon lotor on breeding seabirds at Englefield Bay, Haida Gwaii, Canada
}

\author{
ANTHONY J. GASTON and MICHELLE MASSELINK
}

\begin{abstract}
Summary
Raccoons Procyon lotor were introduced into the Haida Gwaii archipelago of British Columbia in the 1940 s and have spread throughout the islands. Although feeding mainly on inter-tidal invertebrates, they also take seabirds. Haida Gwaii supports internationally important populations of several species of burrow-nesting auks. In 1993, we visited several islands to determine the current status of their seabird populations. We found extensive signs of predation on auks by raccoons, including burrows that had been excavated and carcasses from which little had been eaten, suggesting excess killing. On islands with raccoons, numbers of burrow nesting auks had fallen by as much as $80 \%$ since 1986, whereas on islands without raccoons numbers had remained stable or increased. The evidence obtained suggests that burrow nesting auks will not coexist with raccoons and that once raccoons are established the auk populations will be rapidly extirpated.
\end{abstract}

\section{Introduction}

Raccoons Procyon lotor were introduced to Haida Gwaii (the Queen Charlotte Islands), an archipelago off the northern coast of British Columbia (Figure 1), in the 1940s (Carl and Guiget 1972). Originally, the islands supported a small fraction of the mammal fauna present on the adjacent mainland, the only medium sized carnivores being ermine Mustela erminea, marten Martes americana, river otter Lutra canadensis, and sea otter Enhydra lutris, the last being extirpated from the islands prior to this century (McTaggart-Cowan 1989). Subsequent to their introduction, raccoons spread throughout the main islands (Graham and Moresby islands) and have now reached some of the smaller islands. They favour coastal areas in Haida Gwaii and this preference has probably increased their tendency to disperse among the islands (Hartman 1993).

Haida Gwaii supports large numbers of seabirds, amounting to approximately 1.5 million breeders, of which the commonest species are Cassin's Auklet Ptychoramphus aleuticus (600,00o), Ancient Murrelet Synthliboramphus antiquus $(500,000)$ and Fork-tailed and Leach's Storm-petrels Oceanodroma furcata and leucorhoa (together 300,000) (Rodway 1991). All these species, as well as Rhinoceros Auklets Cerorhinca monocerata, nest in burrows on forested islands. Populations of the three auk species in the archipelago represent 50\% (Ancient Murrelet), $16 \%$ (Cassin's Auklet) and 2\% (Rhinoceros Auklet) of their world 


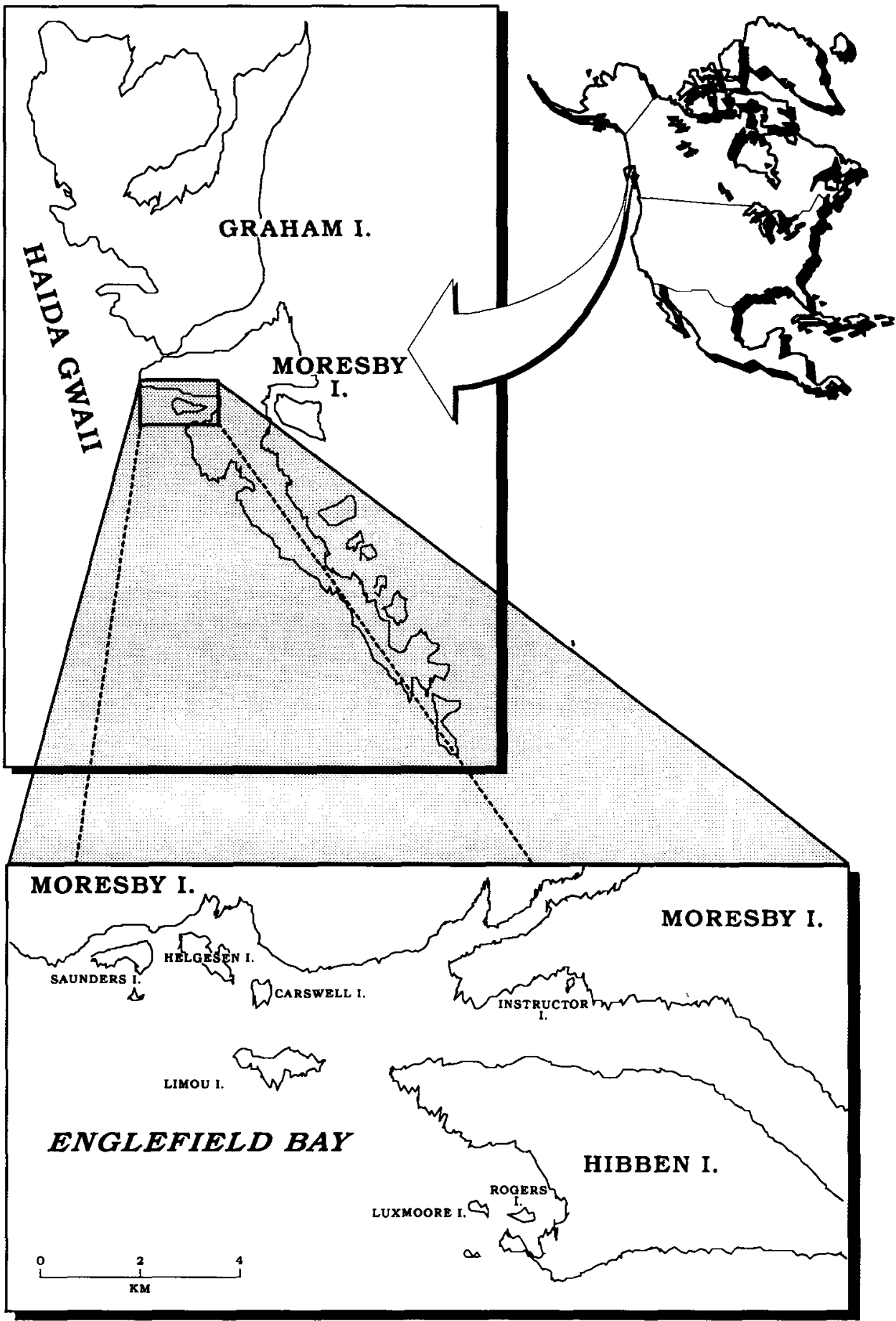

Figure 1. Englefield Bay and Haida Gwaii (Queen Charlotte Islands). 
populations (Rodway 1991). All of the major seabird colonies of Haida Gwaii were censused during 1981-1986 by Canadian Wildlife Service teams, so that a good baseline exists for seabird populations in the area (Rodway et al. 1988, 1990). Research since 1989 suggested that raccoons may pose a severe threat to seabirds in the archipelago (Rodway 1991, Bailey and Kaiser 1993, Gaston 1994).

Evidence obtained from surveys in 1991 (Masselink and Van den Brink 1996) indicated that raccoons were present on many of the smaller islands of Haida Gwaii, including Burnaby and Louise islands, but not on Lyell Island and possibly not on Kunghit Island, although there has been at least one sighting on Kunghit. Raccoons are most numerous on the coast, where they forage in the inter-tidal zone, mainly on invertebrates (Hartman 1993). There are indications that raccoons are still spreading in the islands and it seems to be only a matter of time before they reach all the large islands and many of the smaller ones.

During 1990-1993, studies at a small colony of Ancient Murrelets on East Limestone Island suggested that, although raccoons in Haida Gwaii feed mainly on inter-tidal animals, at a seabird colony they may become specialists on the seabirds during the birds' breeding season (Gaston and Lawrence 1993, Hartman 1993). Even a small number of raccoons may have a disproportionate effect because they indulge in excess killing, leaving many, perhaps most, of the carcasses untouched (Hartman 1993). Raccoons have been strongly implicated in the disappearance of burrow-nesting seabirds from Boulder and Sea Pigeon islands (probably 100-1,000 pairs, Rodway 1991). They have reduced numbers on the Limestone Islands from several thousand to 1,200 pairs (Gaston 1992). However, these colonies are relatively small. No evidence of raccoons causing declines significant on the scale of the regional population have been documented previously.

In 1991, a survey of islands in Englefield Bay, on the west coast of Moresby Island (Figure 1), showed that raccoons were present on Helgesen Island (Masselink and Van den Brink 1996). In 1986, this island was estimated to support 27,000 breeding pairs of seabirds, including 16,000 breeding pairs of Rhinoceros Auklets, 7,000 pairs of Ancient Murrelets and 4,00o pairs of Cassin's Auklets. Raccoons were also present on adjacent Saunders Island where, in 1986, approximately 20,000 burrows of Cassin's Auklets and Rhinoceros Auklets were found deserted (Rodway et al. 1990). No evidence of raccoons has so far been obtained on Carswell, Instructor, Lihou, Rogers or Luxmoore islands, which between them supported 77,000 pairs of seabirds in 1986 (Rodway et al. 1990), or on the large Hibben Island which forms an important potential stepping stone between Moresby Island and the outer islands in Englefield Bay (Figure 1). This paper reports the results of surveys carried out to determine the current status of seabirds on islands in Englefield Bay and the impact of raccoon predation on them.

\section{Study area}

The climate of Englefield Bay is typical of the west coast of Haida Gwaii, being temperate throughout the year with abundant rainfall. Winter minimum temperatures fall just below freezing, while summer maxima rarely exceed 
Table 1. Area and maximum elevation of study islands and their distance from Moresby Island at the nearest point (at high tide)

\begin{tabular}{lccc}
\hline Island & $\begin{array}{c}\text { Area } \\
(\mathrm{ha})\end{array}$ & $\begin{array}{c}\text { Max. elevation } \\
(\mathrm{m})\end{array}$ & $\begin{array}{c}\text { Distance to } \\
\text { Moresby Island (m) }\end{array}$ \\
\hline Saunders Island & 55 & 70 & $200^{\mathrm{a}}$ \\
Helgesen Island & 51 & 114 & 250 \\
Little Helgesen Island & 3 & 15 & 540 \\
Carswell Island & 17 & 80 & 440 \\
Lihou Island & 75 & 120 & 1800 \\
Instructor Island & 2 & 15 & 220 \\
Hibben Island & 3500 & 770 & 1000 \\
Luxmoore Island & 9 & 50 & 2800 \\
Rogers Island & 8 & 60 & 2400 \\
\hline
\end{tabular}

a Via "stepping stone" islets the longest water crossing is $75 \mathrm{~m}$.

$25^{\circ} \mathrm{C}$. Strong winds are a regular feature of the area, especially in late autumn and late winter. Surface water temperatures in the adjacent ocean vary from $6{ }^{\circ} \mathrm{C}$ in January to $12{ }^{\circ} \mathrm{C}$ in August (Thompson 1981). Like the rest of the Haida Gwaii archipelago, the islands of Englefield Bay support primarily a mixed coniferous forest of western hemlock Tsuga heterophylla, Sitka spruce Picea sitchensis and western red cedar Thuja plicata. Small areas of alder Alnus sinuata occur on recently disturbed slopes and near the shore. On islands supporting the introduced black-tailed deer Odocoileus hemionus, the understorey is generally sparse, but where deer are absent (usually small islands well offshore) there is a dense understorey of salal Gaultheria shallon. Areas of open forest and exposed headlands support a ground cover of grass Calamagrostis, but where the canopy is closed the ground vegetation consists mainly of moss. This general description applies to all the islands visited.

Our surveys covered all the main seabird islands in Englefield Bay: Saunders, Helgesen, Little Helgesen, Lihou, Carswell, Instructor, Luxmoore and Rogers. Surface area and distance from Moresby Island at the closest point are given in Table 1. Most of the islands are highly dissected, with many steep gorges cutting across them. Both Helgesen and Lihou islands consist of three hilly sections divided by low waists. Likewise, Luxmoore Island is almost split in two by a deep ravine, while Carswell Island is conical and almost precipitous on all sides. Only the small Instructor Island is relatively flat. Coasts are rocky and steep, with only a narrow inter-tidal zone.

\section{Methods}

The study was conducted from 1 to 28 June 1993 by a team of four people.

\section{Raccoons}

The presence and abundance of raccoons was monitored by (1) spotlight surveys of the inter-tidal zone at night, and (2) searches for "latrines" (see below) along the upper edges of the beach. Spotlight surveys were made either from a kayak or a small inflatable boat powered by an outboard motor. The spotlight generated 1 million candle-power in a narrow beam, enabling eye reflections to 
be picked out at up to $200 \mathrm{~m}$. Observations were made from $20-50 \mathrm{~m}$ offshore. Raccoon scats were frequently concentrated at particular sites ("latrines") placed at the seaward edge of the terrestrial vegetation. The scats were distinguished from those of river otters by their larger diameter and more coherent structure, by their predominant contents and by their position relative to other signs. Most otter latrines were associated with slides, runways or dens, whereas the raccoon latrines were mainly at the base of trees or on slight eminences at the top of the beach.

Englefield Bay was revisited by three people from 8 to 13 November 1993, after the end of the seabird breeding season. At that time two complete and three partial spotlight surveys of the Helgesen and Saunders islands were carried out to count raccoons at a time when they were likely to be feeding entirely in the inter-tidal zone.

\section{Seabirds}

The colonies of Englefield Bay were censused in 1986 (Rodway et al. 1990). The censuses were repeated in 1993 on Helgesen, Lihou and Instructor islands to determine whether the abundance and distribution of seabirds on those islands had changed. This involved counting and identifying all burrows in circular plots placed at intervals along parallel transects, or transects run perpendicular to the shoreline. Transects were placed as nearly as possible on the same lines used in the 1986 survey (which used specified compass bearings) and the intervals between plots were the same (Figures 2 and 3). In 1986, square quadrats were used, varying in size from $9 \mathrm{~m}^{2}$ to $49 \mathrm{~m}^{2}$ and at intervals of 30 or $50 \mathrm{~m}$. We used $25 \mathrm{~m}^{2}$ circular plots throughout, as straight-sided quadrats were difficult to lay out on the uneven terrain. Although we kept as closely as possible to the positions of the original survey plots, it is unlikely that we found exactly the same areas, especially on lengthy interior transects. Sixty-two circular plots were counted along the 11 transects in the central and southern sections of Helgesen Island; an aggregate of $1550 \mathrm{~m}^{2}$ (Figure 2). On Lihou Island, 110 plots were counted on 14 transects, aggregating $2,750 \mathrm{~m}^{2}$ (Figure 3)

Seabird burrows were identified on the basis of their entrance diameters (Rhinoceros Auklets $>12 \mathrm{~cm}>$ Ancient Murrelets $=$ Cassin's Auklets $>$ $8 \mathrm{~cm}>$ storm-petrels) and Cassin's Auklet burrows were distinguished from those of Ancient Murrelets by the presence of dropping streaks at the entrance, the characteristic smell, and their situation in rather dense groups at or near the seaward edge of the vegetation. Some unoccupied Cassin's Auklet burrows, lacking smell or droppings, may have been confused with Ancient Murrelets.

It is possible to distinguish between hatched eggs and those taken by predators during incubation because the membrane inside the shell thickens near hatching (Gaston 1992). All evidence of predation and of hatched eggshells on the census plots was recorded, as well as any predation evidence or hatched eggshells found within $5 \mathrm{~m}$ of the transect line. All predation remains were assigned to the 1993 or earlier seasons on the basis of their condition. Remains including fresh blood were assumed to be of birds killed the previous night.

Burrow occupancy was determined for samples of Ancient Murrelet burrows on Helgesen Island by examining burrows, digging access to nest chambers 


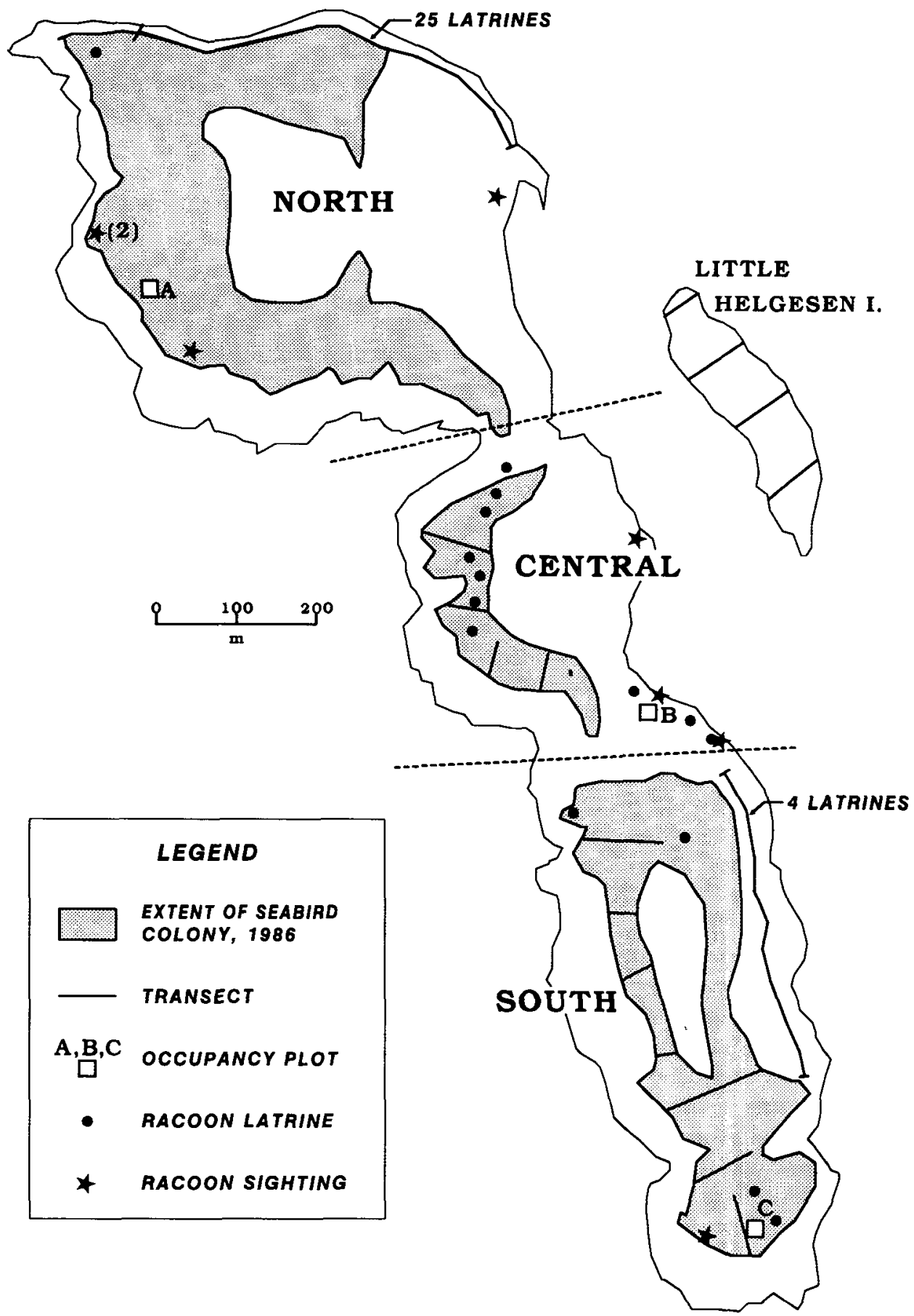

Figure 2. Helgesen Island, showing the position of census transects, predation study area, raccoon scat searches, and latrines located in June 1993 and areas occupied by burrow-nesting auks in 1986 (latter after Rodway et al. 1990). Burrow-nesting auks were absent from the north section in 1993. 


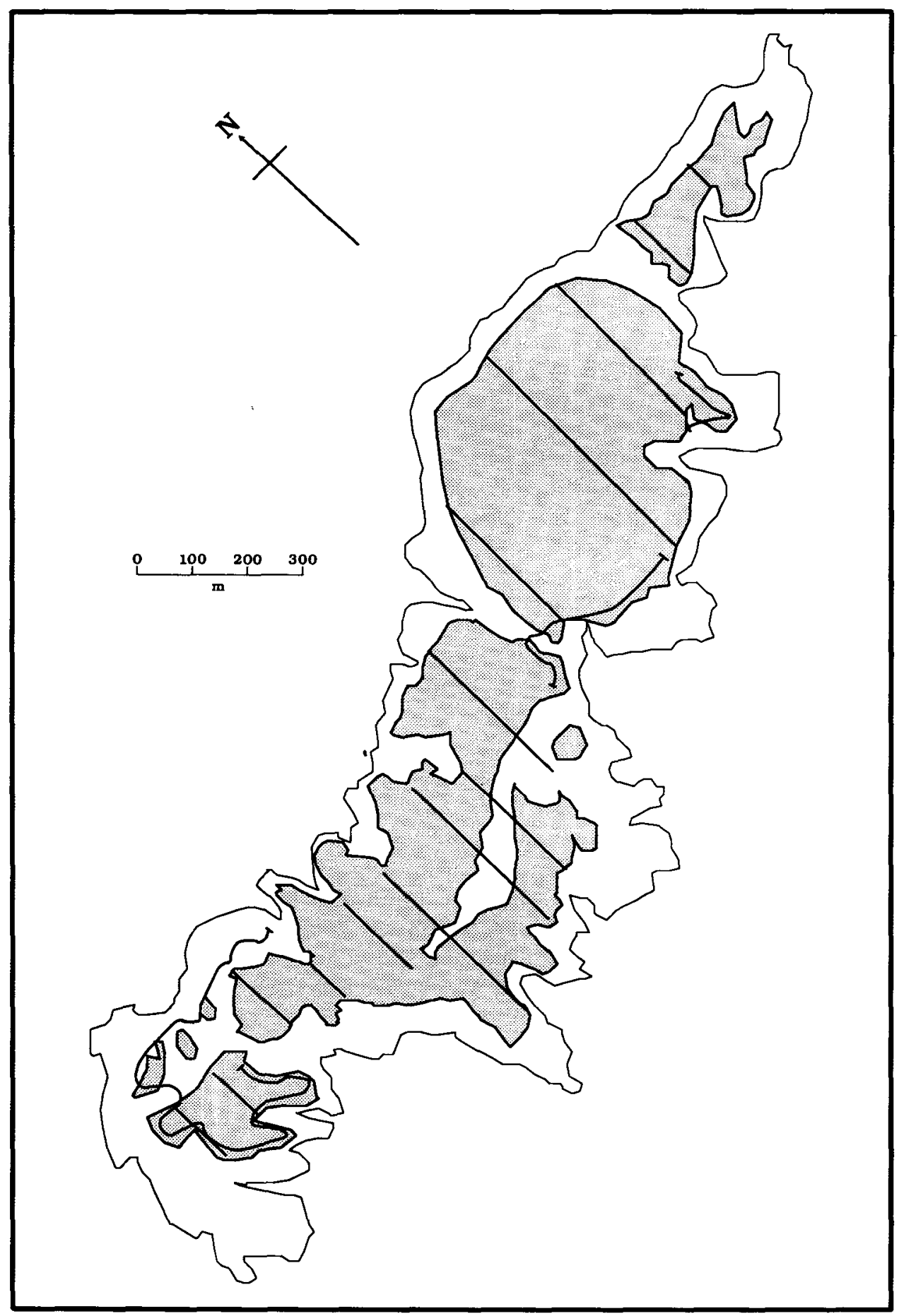

Figure 3. Lihou Island, showing census transects (straight lines), raccoon scat searches (meandering lines) and the areas occupied by burrow-nesting auks (shaded) in June 1993. 
where necessary. By the time of our survey, most Ancient Murrelets had finished breeding. Burrows were considered to have been occupied in 1993 if fresh eggshell or egg membrane was found (this method is $>95 \%$ reliable, Gaston et al. 1988). Occupancy for Rhinoceros Auklets was determined by erecting tags in burrow entrances and recording knock-downs daily for three consecutive days. Breeding Rhinoceros Auklets usually enter burrows nightly to exchange incubation duty or feed the chick (Wilson and Manuwal 1986, Bertram et al. 1991). We considered burrows occupied if tags were knocked down on at least two out of three nights. Occupancy of Cassin's Auklet burrows was judged from the proportion having the characteristic smell of regurgitations and signs of defecations at the entrance.

In addition to the transect censuses, all islands (Saunders, Helgesen, Little Helgesen, Carswell, Instructor, Luxmoore and Rogers) were surveyed by observers walking randomly through the colony areas mapped in 1986, assessing the state of burrows seen and counting evidence of predation, including notes on the likely age of the predations and the state of the remains (feathers only, wings, breast bones, complete carcasses). Rates of predation were determined for one area in the central section of Helgesen Island (Figure 2) by marking all evidence of predation and resurveying the area for new evidence of predation after 10 days.

\section{Results}

\section{Raccoons}

Evidence of raccoons was seen on Saunders (scats, tracks, some recent), Helgesen (scats, spotlight observations, Figure 2), and Instructor islands (only one latrine, not recent) and on the adjacent coast of Moresby Island (scats, tracks). No evidence was found on Lihou, Luxmoore or Rogers islands (scat transects only), on Carswell island (scat transects and spotlight observations on two nights), on Little Helgesen Island (scat transects, spotlight observations on four nights), or on the large Hibben Island (scat transects), to which Luxmoore and Rogers islands are closely adjacent.

Spotlight observations of raccoons at Helgesen Island on five nights during 721 June revealed $0,1,1,3$ and 3 raccoons. However, the distribution of animals suggested that probably at least four individuals were present. All except one, on the northern section of the island, were seen close to the edge of the vegetation, rather than in the inter-tidal zone where they normally forage in the absence of seabirds (Hartman 1993).

All of the 163 raccoon scats found on the north coast of Helgesen Island comprised entirely marine invertebrate (amphipod, crab, periwinkle, mussel and limpet) or fish remains. However, 29 of $72(40 \%)$ found in the central section of the island contained exclusively feathers, while 16 of $37(43 \%)$ found at the south end contained feathers (comparing the proportions of scats containing feathers in the three areas, $\chi^{2}=80.8, d f 2, P<0.001$ ). In the central and southern parts of Helgesen Island, all 13 recent scats (within 48 hours) comprised exclusively feathers of resident burrow-nesting auks (Cassin's Auklet, Ancient Murrelet and Rhinoceros Auklet). 
On Helgesen Island, some excavated burrows were found. Evidence of excavations was especially abundant (relative to the population) for Cassin's Auklets, for which at least 12 cases of digging were found (among 200 occupied, see below). Evidence of excavation was found at 15 Rhinoceros Auklet burrows, including five where raccoon hairs and/or prints were present and at three Ancient Murrelet burrows, including one where hairs were present. Two headless corpses were found from which little meat had been eaten, one of an Ancient Murrelet and one of a Cassin's Auklet. Such decapitation with little or no meat taken is characteristic of raccoon predation elsewhere in Haida Gwaii (pers. obs.). Two Rhinoceros Auklet carcasses were found with their necks broken; one intact and one with a little breast meat eaten. Rhinoceros Auklets, being larger than the other auks, may have been too difficult to decapitate.

During the two complete surveys of Helgesen Island in November we recorded six and seven raccoons feeding in the inter-tidal zone. A further eight were seen on three partial surveys. From the position of the animals and the composition of the parties, we estimated that the number present was at least 12. Fourteen of $21(67 \%)$ sightings were in the inter-tidal zone, close to the water's edge (comparing June with November for the proportion in the inter-tidal zone, Fisher exact $P=0.014$ ). A maximum of two raccoons were seen on two complete surveys of Saunders Island during the same period. None was seen on either Carswell or Little Helgesen islands.

\section{Seabird populations}

Saunders Island (raccoons present) As in 1986, we found no evidence of occupancy by burrow-nesting seabirds, although many burrows were still apparent, especially those on exposed headlands where little litter fall had occurred. No predation remains were found.

Helgesen Island (raccoons present) We found little evidence of burrow nesting seabirds on the northern section of the island, although burrows were still visible in many places. No Rhinoceros Auklet or Ancient Murrelet burrows were occupied and only one Cassin's Auklet burrow (Table 2). No arrivals or calls were detected in two nights of observations at one area with many Rhinoceros Auklet and Ancient Murrelet burrows. Evidence of fresh predation was rare, but 35 Rhinoceros Auklet skeletons dating from previous years were found in the area of the former Rhinoceros Auklet colony. Because there was little evidence of burrow occupation on the northern section, we did not census burrows there.

On the central section of Helgesen Island about one quarter of burrows of all species were occupied and a total of 18 burrows were found to have been dug into by some mammal (Table 2). No hatched Ancient Murrelet eggshells were found on the surface. On 16 June, the remains of at least 16 predations of Ancient Murrelets were found on the predation plot in the central section. Two more were found on 26 June, but most Ancient Murrelets had probably completed breeding by then. On 26 June the remains of a minimum of 31 
Table 2. Breeding and predation evidence found on the three sections of Helgesen island in 1993

\begin{tabular}{lrrr}
\hline Section Evidence & \multicolumn{3}{c}{ Species } \\
\cline { 2 - 4 } & $\begin{array}{r}\text { Ancient } \\
\text { Murrelet }\end{array}$ & $\begin{array}{r}\text { Rhinoceros } \\
\text { Auklet }\end{array}$ & $\begin{array}{c}\text { Cassin's Auklet } \\
\text { North }\end{array}$ \\
Percentage occupancy $(n)$ & $0(25)$ & $0(25)$ & $2(52)$ \\
Hatched eggshell & 0 & 0 & 0 \\
Fresh predations & 5 & 1 & 0 \\
Excavated burrows & 0 & 0 & 0 \\
Central & & & \\
Percentage occupancy $(n)$ & $22(18)$ & $24(25)$ & $40(10)$ \\
Hatched eggshell & 0 & 0 & 0 \\
Fresh predations & 18 & 31 & 0 \\
Excavated burrows & 1 & 11 & 6 \\
South & & & \\
Percentage occupancy $(n)$ & $?$ & $76(25)$ & $\mathbf{1 8}(22)$ \\
Hatched eggshell & 11 & 2 & 0 \\
Fresh predations & 35 & 17 & 3 \\
Excavated burrows & 2 & 5 & 6 \\
\hline
\end{tabular}

Rhinoceros Auklets killed by predators, none of which had been present on 16 June, were found in the same area.

On the southern section of Helgesen Island we found much evidence of breeding and of predation (Table 2). No attempt was made to determine occupancy for Ancient Murrelets, but 11 fragments of eggshell with egg membranes were found, suggesting that the chicks had hatched. At the extreme southern tip of the island $76 \%$ of Rhinoceros Auklet burrows were occupied and $96 \%$ were entered at least once in three nights. On the night of 25-26 June most Rhinoceros Auklets arriving in that area were carrying fish, indicating that chicks had hatched.

Census plots contained 42 Ancient Murrelet, 107 Rhinoceros Auklet and 20 Cassin's Auklet burrows. Using densities based on those plots falling within the areas occupied by Ancient Murrelets and Rhinoceros Auklets (62 and 36 plots respectively) and the occupancy rates given in Table 2, we estimated total populations as 1,139 and 3,261 pairs, or $17 \%$ and $21 \%$ of the populations estimated in 1986 (Table 3).

Estimating the population of Cassin's Auklets by extrapolating from the few plots in which they occurred (five) is unlikely to give a realistic estimate. Most Cassin's Auklet burrows on any of the islands visited occurred within $20 \mathrm{~m}$ of the seaward edge of vegetation. We searched the edge of the vegetation over most of the island, but signs of occupation were evident in only two areas, one of which was not included in the transects. We counted 60 burrows, of which only 15 were occupied. Allowing for the possibility of a few small pockets missed, we estimated no more than 800 burrows on Helgesen Island. Using the observed occupancy rate of $25 \%$ this suggests about 200 breeding pairs.

Little Helgesen Island (no evidence of raccoons) This small island lies $150 \mathrm{~m}$ from Helgesen Island at the closest point. Rodway et al. (1990) estimated 950 pairs of Rhinoceros Auklets and 860 pairs of Ancient Murrelets breeding in 1986. We 


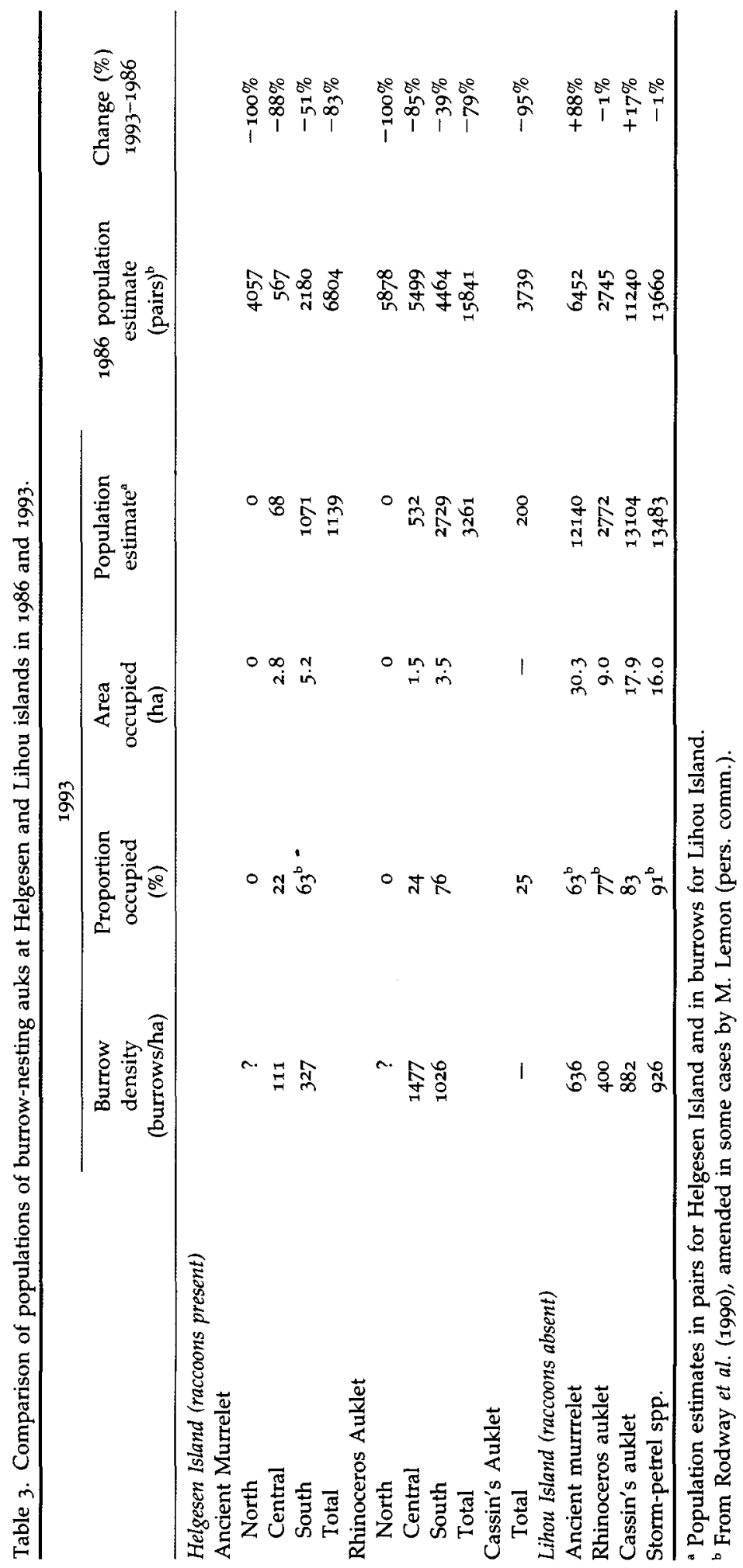


located many Rhinoceros Auklet burrows on the south-eastern third of the island, but found no evidence of breeding (eggshells, feathers). Only one Rhinoceros Auklet landed in three night-time watches at an area containing at least 60 burrows. Night time observations showed that many Rhinoceros Auklet burrows were entered by Fork-tailed Storm-petrels, accounting for their used appearance. We recorded six Ancient Murrelet burrows in seven census plots (400 burrows/ha), somewhat less than reported by Rodway et al. (1990; 860 burrows/ha). Ancient Murrelets were singing on the island on 15 and 16 June and on 15 June a family party departed to sea, confirming that successful breeding had occurred. One Rhinoceros Auklet skeleton and evidence of one recently killed Ancient Murrelet were found. We concluded that Ancient Murrelets bred on the island in small numbers, but that Rhinoceros Auklets had largely deserted the island. We found no evidence of raccoons on five spotlight surveys.

Lihou Island (no evidence of raccoons) This is a relatively large island situated further from the large islands of Moresby and Hibben than any of the other seabird islands. At the closest point it is $1.1 \mathrm{~km}$ from Bone Point, Hibben Island and $1.8 \mathrm{~km}$ from Moresby Island. No evidence of raccoons has ever been found on it. It is very similar in vegetation and topography to Helgesen Island and we censused it intensively to provide a control for observations there.

Widespread remains of predations and eggshells, and the used appearance of the burrows, suggested that the entire vegetated portion of the island was occupied by burrow-nesting seabirds (Figure 3). We found no signs of burrows of any species having been dug into. Ancient Murrelets bred over most of the island; we counted 175 burrows in 110 plots (636 burrows/ha), of which 62 plots contained at least one burrow. We found the remains of 18 hatched eggshells and 39 adult birds, including four carcasses from which most of the meat had been removed.

We found 29 Rhinoceros Auklet burrows in 14 plots, compared with 24 burrows in 10 plots in 1986 (Rodway et al. 1990). Our estimate of density, based on all plots within the area occupied (29), was 400 burrows/ha, compared with 505 burrows/ha reported by Rodway et al. Occupancy was not recorded in either year. Eight sets of Rhinoceros Auklet remains were found, including two skeletons.

Among 15 census plots containing at least one Cassin's auklet burrow, we found 75 burrows, compared with 76 burrows in 21 plots (correcting for differences in the sizes of some plots) reported by Rodway et al. (1990). Our density estimate from the 34 plots within the colony was 882 burrows/ha, very similar to that of Rodway et al. (837 burrows/ha). Among burrows examined, $83 \%$ showed signs of occupation. Rodway et al. also reported regurgitations at many burrows.

The distribution of storm-petrel burrows was similar to that reported by Rodway et al. (1990). They were most abundant on the eastern half of the island, with up to 1 burrow $/ \mathrm{m}^{2}$ in places. Burrows were present in 35 census plots and we found 132 altogether, giving an estimated density of 926 burrows/ha (57 census plots were considered within the storm-petrel colony), compared with 938 burrows/ha reported by Rodway et al. 
Because neither we nor Rodway et al. (1990) estimated burrow occupancy, we cannot compare absolute population estimates. However, based on the median occupancy rates for Haida Gwaii given by Rodway et al. (63\%), our census suggested a population of about 12,000 pairs of Ancient Murrelets, compared with 6,500 estimated in 1986. Our estimate would make Lihou Island the seventh largest colony of Ancient Murrelets in British Columbia. All of the areas occupied in 1986 were still active in 1993, judging from predation and egg-shell remains and the state of burrows.

Carswell Island (no evidence of raccoons) No census was carried out on this island, which was not censused in 1986 either. We surveyed it for evidence of breeding seabirds and raccoons, but covered only the northern half. Ancient Murrelet burrows and several pockets of Cassin's Auklet burrows were found on the north side of the island, where they were not reported by Rodway et al. (1990). All but two of 40 Cassin's Auklet burrows examined showed signs of occupation this year $(95 \%)$. We found the remains of 22 Ancient Murrelets, and two Rhinoceros Auklets killed by predators, as well as four hatched Ancient Murrelet eggshells.

Instructor Island (no evidence of raccoons, except signs of excavated burrows) This small island is situated only $220 \mathrm{~m}$ from the nearest part of Moresby Island. We repeated the transects carried out by Rodway et al. (1990), finding similar numbers of burrows (they estimated 764 pairs of Ancient Murrelets and 848 pairs of Rhinoceros Auklets). However, we found no evidence of recent occupation by any burrow-nesting auks. Instead, we found that four contained incubating Fork-tailed Storm-petrels, two more contained broken storm-petrel eggshells and a further seven smelled of storm-petrels. Some burrows appeared to have been excavated through the roof of the nest chamber, but such excavations dated to previous years. One recently excavated burrow contained an incubating storm-petrel.

Luxmoore and Rogers islands (no evidence of raccoons) These islands are important mainly for their large Storm-petrel populations. In 1986, they supported only a few thousand pairs of Ancient Murrelets and a few hundred pairs of Rhinoceros and Cassin's Auklets (Rodway et al. 1990). We visited them for one day, mainly to look for signs of raccoons. On Rogers Island, we found many river otter Lutra canadensis scats containing feathers and there were abundant signs of recent predation (30 Fork-tailed and 60 Leach's Storm-petrels and six Ancient Murrelets). Storm-petrel burrows were very dense, exceeding $1 / \mathrm{m}^{2}$ in places. On Luxmoore Island we again found river otter scats containing feathers and the recent remains of 17 Fork-tailed and two Leach's Storm-petrels, nine Ancient Murrelets and one Rhinoceros Auklet.

\section{Discussion}

Our strongest evidence for the impact of raccoons comes from the comparison of affected and unaffected islands. All of the islands where numbers of auks 
have diminished either supported raccoons during our visit (Saunders, Helgesen), or are so close to potential source areas $(<250 \mathrm{~m})$ that visits by raccoons seem very probable (Little Helgesen, Instructor). At Saunders Island, burrow-nesting auks had already disappeared in 1986. At Helgesen, Little Helgesen and Instructor islands, numbers have been severely reduced, whereas at Lihou Island numbers of Ancient Murrelets have probably increased and numbers of Cassin's and Rhinoceros Auklets appear roughly unchanged. Judging from the extension of their breeding areas, numbers of Ancient Murrelets and Cassin's Auklets breeding on Carswell Island may also have increased, but without a proper baseline census it is difficult to be sure. The high occupancy of Cassin's Auklet burrows at Carswell Island makes a strong contrast with nearby Helgesen Island. Rodway et al. (1990) noted that there was little evidence of activity on Instructor Island, so this island may have already been partially deserted in 1986. The presence of good numbers of storm-petrels on Little Helgesen and Instructor islands suggests that these birds are more resistant to raccoon predation than the burrow-nesting auks, but we cannot account for this difference at present.

If we accept the occupancy rates used for the 1986 census, then perhaps $80 \%$ of Rhinoceros Auklets and Ancient Murrelets have gone from Helgesen Island, and as many as $95 \%$ of Cassin's Auklets. In 1986, only six burrows were found excavated by predators and only four breast bones and one carcass, chewed around the neck but not decapitated, were found. Rodway et al. (1990) found an occupancy rate for Ancient Murrelets similar to the mean for British Columbia $(63 \%)$, which suggests that the population of murrelets had been little affected up to 1986. Moreover, in June 1987, M. Lemon (pers. comm.) visited Helgesen Island briefly and excavated six Rhinoceros Auklet burrows containing eggs at the south-western corner of the north section. Consequently, it is certain that at least part of the north section was still occupied in 1987. These observations all suggest that the effect of raccoon predation at Helgesen Island was relatively small up to $1986-1987$. Most of the population declines appear to have taken place since then.

Lihou Island, in contrast to Helgesen Island, showed no sign of seabird population decreases. Signs of active breeding by Ancient Murrelets and Rhinoceros Auklets were present throughout the area mapped by Rodway et al. (1990). The proportion of Cassin's Auklet burrows that we found occupied was similar to the provincial average (75\%, Rodway 1991) and much higher than at Helgesen Island. Because neither we, nor Rodway et al. (1990), measured occupancy rates for Ancient Murrelets and Rhinoceros Auklets on Lihou Island, we cannot exclude the possibility that burrow occupancy there had changed. However, most Rhinoceros Auklet burrows at Lihou showed signs of recent entry, in the form of scratching and lack of cobwebs, whereas most burrows on the north section at Helgesen Island did not. Ancient Murrelets have probably increased on Lihou Island, where we found the density of burrows to be approximately double that found by Rodway et al. (1990).

The difference in population trends between islands with and without raccoons, taken with the evidence of heavy raccoon predation on seabirds (feathers in scats, excavated burrows), strongly suggests that raccoon predation has been the primary cause of the observed declines, causing the elimination of some 
10,000 pairs of Rhinoceros Auklets (about 30\% of the Haida Gwaii population, Rodway 1991) and 5,000 pairs of Ancient Murrelets in seven years. Helgesen Island previously supported the seventh largest Rhinoceros Auklet colony in Canada. The fact that the seabirds breeding at the north end of Helgesen Island have suffered more than those at the south end also fits the hypothesis that raccoon predation is the main cause, as the island is closest to Moresby Island at its northern tip and separated only by a sheltered channel. Raccoons would almost certainly have made their first landing there.

Considerable evidence of predation, in the form of feathers and skeletal remains, is normal on seabird colonies throughout Haida Gwaii, irrespective of the presence of raccoons (Rodway et al. 1988, 1990, Gaston 1992). The main predators appear to be Bald Eagles Haliaeetus leucocephalus and Ravens Corvus corax (Gaston 1992). However, the evidence seen at Helgesen Island was unusual in the large number of Rhinoceros Auklet skeletons found (35 vs 2 at Lihou Island) and in the number of burrows that had been excavated. Rodway et al. (1990) reported only two burrows showing signs of excavation on Helgesen in 1986, compared with 24 found in 1993. Comparison of our spotlight observations in June and November confirms that raccoons in Haida Gwaii will switch from feeding in the inter-tidal zone to feeding on seabirds when they arrive on seabird colonies (Hartman 1993). Outside the breeding season (November) they reverted to inter-tidal feeding.

The apparent stability or increase in seabird populations at Lihou Island suggests that the declines observed at Helgesen and Saunders islands were probably not caused by regional changes in the availability of food, or any factor operating away from the breeding colonies. Moreover, there was no evidence that the large numbers of Rhinoceros Auklets lost from Helgesen Island had moved to other islands nearby, although the increase in numbers of Ancient Murrelets at Lihou Island could have been partly the result of birds relocating from Helgesen Island.

The elimination of approximately 30,000 auks from Helgesen Island in the space of seven years seems a very rapid decline. However, the observations made in November suggest that the island supported many more raccoons than was apparent from the spotlight surveys made in June. It seems unlikely that there would have been a net increase in the number of raccoons on the island between June and November (as food would have diminished after the departure of the seabirds), although some animals seen in November might have been dependent kits in June. The main reason for the underestimate of raccoons in June seems to be that they were foraging mainly in the forest at that season. Hartman (1993) estimated that raccoons at East Limestone Island killed one Ancient Murrelet per animal per day. Given the excess killing habits of the raccoons and the fact that Helgesen is a much denser colony than East Limestone (mean density of Ancient Murrelet burrows 191/ha, no Rhinoceros Auklets, and very few Cassin's Auklets), we might expect a greater rate of predation at Helgesen Island. The combined breeding season of all the burrownesting auks extends from about 1 April to mid-August (dates for Ancient Murrelets, Sealy 1976; for Rhinoceros Auklets, Bertram et al. 1991), i.e. about 135 days. Assuming a kill of two birds per raccoon per day, and 12 raccoons present throughout the season, they could have accounted for approximately 3,00o auks 
in a single year. Adding reduced recruitment caused by breeding failure where one member of a pair had been killed, the estimated population reductions appear to be possible based on raccoon predation alone. More than 12 raccoons may have been present at times, when the colony was larger. The fact that larger numbers of raccoons were seen during spotlight surveys on Helgesen Island than on Saunders Island, an island of similar size, and with a much larger inter-tidal zone, suggests that raccoons may reach higher densities on seabird colonies than on similar islands without seabirds, presumably in response to the abundant food provided by the birds. Alternatively, they may move on and off the islands in response to seasonal presence of the birds. However, in both June and November 1993 and in September 1995, raccoons were scarce on the shore of Moresby Island adjacent to Helgesen Island (AJG, Anne Harfenist pers. comm.), suggesting that those present on Helgesen Island may have been mainly resident.

Taken together, our observations suggest that burrow-nesting auks are not able to coexist with raccoons and that islands close enough to source areas to allow colonization will soon lose their auks unless measures are taken to control raccoons. Carswell Island, with a population of several thousand burrow nesting auks in 1986 (Rodway et al. 1990) seems to be the most vulnerable. The relatively isolated Lihou Island is now the most important seabird colony in Englefield Bay and the one most readily protected against raccoons. Immediate action is required to secure the future of this colony.

\section{Acknowledgements}

We thank our companions in the field, Jane Whitney and Stephen Smith, for their excellent support and hard work. Many thanks to Terry and Charlotte Husband and Keith and Barbara Rowsell for assistance with logistics. The study was funded by the Canadian Wildlife Service.

\section{References}

Bailey, E. P. and Kaiser, G. W. (1993) Impacts of introduced predators on nesting seabirds in the northeast Pacific. Pp. 218-226 in K. Vermeer, K. T. Briggs, K. H. Morgan and D. Siegel-Causey, eds. The status, ecology and conservation of marine birds of the north Pacific. Ottawa, Canada: Canadian Wildlife Service (Special Publ.).

Bertram, D. F., Kaiser, G. W., and Ydenberg, R. C. (1991) Patterns in the provisioning and growth of nestling Rhinoceros Auklets. Auk 108: 842-852.

Carl, G. C. and Guiget, C. J. (1972) Alien animals in British Columbia, Second edition. Victoria, British Columbia: British Columbia Provincial Museum (Handbook 14).

Gaston, A. J. (1992) The Ancient Murrelet: a natural history in the Queen Charlotte Islands. London: Poyser.

Gaston, A. J. (1994) The status of the Ancient Murrelet, Synthliboramphus antiquus in Canada and the effects of introduced predators. Can. Field-Natur. 108: 211-222.

Gaston, A.J., and Lawrence, A. (1993) Laskeek Bay Conservation Society: report on scientific activities in 1992. Queen Charlotte City, British Columbia: Laskeek Bay Conservation Society.

Gaston, A. J., Jones, I. L. and Noble, D. G. (1988) Monitoring Ancient Murrelet breeding populations. Col. Waterbirds 11: 58-66. 
Hartman, L. (1993) Ecology of raccoons (Procyon lotor) in the Queen Charlotte Islands, British Columbia, and evaluation of their potential impact on native burrow-nesting seabirds. MSc. thesis, University of Victoria, Victoria, British Columbia.

Masselink, D. and Van den Brink, M. (1996) Raccoon-seabird interactions in the Queen Charlotte Islands: a progress report for the 1991-92 field season, part 1. Synoptic work. Ms report to British Columbia Ministry of Environment, Land and Parks.

McTaggart-Cowan, I. (1989) Birds and mammals of the Queen Charlotte Islands. Pp. 175186 in G. G. E. Scudder and N. Gessler, eds. The outer shores. Queen Charlotte City, British Columbia: Queen Charlotte Islands Museum Press.

Rodway, M. S. (1991) Status and conservation of breeding seabirds in British Columbia. Pp. 43-102 in J. P. Croxall, ed. Seabird status and conservation: a supplement, Cambridge, U.K.: International Council for Bird Preservation (Tech. Publ. )11.

Rodway, M. S., Lemon, M. and Kaiser, G. W. (1988) Canadian Wildlife Service seabird inventory report, 1. East coast of Moresby Island. Delta, British Columbia: Canadian Wildlife Service, Pacific and Yukon Region (Techn. Report 50).

Rodway, M. S., Lemon, M. and Kaiser, G. W. (1990) Canadian Wildlife Service seabird inventory report, 2: West coast of Moresby Island. Delta, British Columbia: Canadian Wildlife Service, Pacific and Yukon Region (Techn. Report 65).

Sealy, S. G. (1976) Biology of nesting ancient murrelets. Condor 78: 294-306.

Thompson, R. E. (1981) Oceanography of the British Columbia coast. Ottawa, Canada: Dept. Fisheries and Oceans (Special Publ. 56).

Wilson, U. H. aıd Manuwal, D. A. (1986). Breeding biology of the Rhinoceros Auklet in Washington. Condor 88: 143-155.

\section{ANTHONY J. GASTON}

Canadian Wildlife Service, National Wildlife Research Centre, 100 Gamelin Blvd., Hull, Quebec, Canada $\mathrm{K}_{1} \mathrm{~A} \mathrm{oH}_{3}$

MICHELLE MASSELINK

Appt. 209, 1380 Foothills Blvd., Prince George, British Columbia, Canada V2M $6 \mathrm{V8}$ 